\title{
Hizmet Kalitesinin Servqual Ölçeği İle Ölçülmesi: Uşak Üniversitesi Merkez Kütüphanesi Üzerine Bir Araştırma
}

\author{
Polat Can*
}

Uşak Üniversitesi, İletişim Fakültesi, Halkla İlişkiler ve Reklamcılık Bölümü, Uşak.

\begin{abstract}
$\ddot{O} z$
Hizmet işletmelerinde kalite; anlaşılması, uygulaması ve sonuçlarının değerlendirilmesi bakımından güç ve karmaşık kavramlardan birisidir. Hizmetler elle tutulamayan ürünler arasında olduğu için, aynı kalitenin sağlanması ve sunulması işletmeler açısından oldukça zor olmaktadır. Hizmetlerin kalitesinin ölçümü ise müşterilerin beklentileri ve algıları arasındaki farkların incelenmesi ile gerçekleştirilmektedir. Kar amacı gütmeyen ancak hizmet üreten işletmeler olarak kütüphanelerin sağladıkları hizmetlerin kalite düzeyinin iyileştirebilmesi hizmet kalitesinin somut ve sağlam verilere dayalı bir şekilde ölçülmesine bağhıdır. Çalışmanın amacı, kütüphanelerde hizmet kalitesinin ölçümüdür. Bu amaç doğrultusunda, Uşak Üniversitesi Merkez Kütüphanesi araştırma kapsamına alınmış ve kütüphaneden yararlanan 400 öğrenciye anket uygulanmış ve hizmet kalitesi ölçümü için Servqual Hizmet Kalitesi ölçeğinden yararlanılmışıır. Verilerin analizinde ortalama, frekans dağıllımı, Sevqual skoru, korelasyon analizi ve eşleştirilmiş̧ örneklem testi kullanılmışır.
\end{abstract}

Anahtar Kelimeler: Hizmet Pazarlaması, Hizmet Kalitesi, Servqual Hizmet Kalitesi Ölçümü, Kütüphane

\section{The Measurement of Service Quality with Servqual Scale: A Research on Uşak University Central Library}

\begin{abstract}
The quality in service business is one of the difficult and complicated concepts in terms to its application and the evaluation of its results. As the services are among the intangible products, to maintain the same quality and to serve it is quite difficult in terms of the business enterprises. As for the measurement of service, it is realised if the disparity between the exectations and perceptions of consumers are analysed. The improvement of the quality level of services that libraries provide as a non-profit-making but serving enterprises depends on the tangible and reliable data measurement. The purpose of this study is the measurement of quality at libraries. In accordance with this purpose, the Central Library of Uşak University is included in scope, 400 students benefiting from the library are surveyed and Servqual Measurement Scale has been benefited. In the analyses of acquired data, average, frequency distribution, Sevqual score, correlation analysis and paired sample test have been put to use.
\end{abstract}

Keywords: Services Marketing, Service Quality, Service Quality Measurement of Servqual, Library

\section{GíRiş}

Günümüzde hizmet kavramının önemi gittikçe artmakta ve bunun sonucu olarak çok fazla incelenmektedir. Hizmet, çıktılarının soyut olduğu, çok fazla alanda karşılaşılan, gelişime açık, süreklilik taşıyan, rekabetin yoğun olduğu çok boyutlu bir sektördür. Hizmetlerde standardı yakalamanın güçlügüu, üretim ve tüketimin eşzamanlı olması, performans değerlendirmesinin tüketicilerin algısına bağlı olması 
gibi nedenden dolayı işletmelerin kendilerini tüketiciye kabul ettirmesi ve faaliyetlerini sürdürmesi zor olmaktadır.

Üniversite kütüphaneleri bilgi üreten birer hizmet işletmeleri gibi faaliyetlerini sürdürmektedir. Bu kütüphanelerin amaçları; talep edilen bilgiyi kullanıcılarına en kısa sürede ve doğru bir şekilde sunmaktır. Bu amaca ulaşmada verilen hizmetin kalitesi büyük önem taşımaktadır. Geleneksel olarak akademik kütüphanelerin hizmet kalitesi genellikle sahip oldukları koleksiyonun genişliğine ve nicelik bakımından elinde bulundurduğu yayınlanmış malzemeye esasına göre belirlenmektedir. Uzun yıllar bu alanda yapılan çalışmalarda hizmet kalitesi, kullanıcı istekleri ve görüşleri doğrultusunda belirlenmeye çalışılmıştır.

Son yıllarda ise kütüphane hizmet kalitesinin ölçülmesinde araştırmacılar, pazarlama ve tüketici davranışları üzerine yoğunlaşarak, kullanıcı beklentileri ve bunun sonucunda algılanan kalite bağlamında hizmet kalitesini belirlemeye çalışmaktadırlar. Kalitenin bu bakış açısından incelenmesi, sadece kullanıcıların kaliteyi değerlendirmesi diğer değerlendirmelerin geçersiz olduğu görüşünün yaygınlaşmasına neden olmaktadır.

Hizmet kalitesini ölçmek için geliştirilmiş, kütüphaneler için uygun, oldukça yeni ve faydalı birçok yöntem bulunmaktadır. Bu ölçüm metotları sayesinde kütüphaneler, sunduğu hizmetin kalitesini ölçmekte, bunun sonucunda kontrol sistemini oluşturabilmektedir. Hizmet kalitesi ölçüm yöntemleri arasında en fazla kabul göreni, Parasuraman, Zeithaml ve Berry tarafından geliştirilen Servqual modelidir.

Çalışmanın bundan sonraki kısmında hizmet, kalite, hizmet kalitesi, hizmet kalitesi modelleri ve Servqual ölçeği teorik çerçeve başlı̆̆ı altında ele alındıktan sonra, kütüphane hizmet kalitesi alanında Servqual ölçeği kullanılarak yapılmış bazı araştırmalardan bahsedilmiştir. Son kısımda ise, Uşak Üniversite kütüphanesi üzerine yapılan araştırmanın yöntemi, verilerin analizi ve araştırmadan elde edilen sonuçlar yer almaktadir.

\section{TEORIKK ÇERÇEVE}

\subsection{Hizmet Kavramı}

Hizmetin son yıllarda önemli bir kavram haline gelmesi, bu konuda çok sayıda çalışmanın yapılmasına neden olmuştur. Hizmet terimi neredeyse her sektörde önem verilen ve işletmelerin üzerine hassas şekilde durduğu rekabet aracı halini almıştır (Gürbüz ve Ergülen, 2006: 174). Hizmetlerle ilgili yapılan çalışmalar incelendiğinde, kavramın genel kabul görmüş ortak bir tanımının olmadığ1 ve hizmetin sektörlere göre farklı şekillerde tanımlandığı görülmektedir (Çiçek ve Doğan, 20009: 201). Hizmet terimi, içinde bulunulduğu döneme, araştırmacının bakış açısına, sektörün yapısına ve işletmenin faaliyet alanına göre kapsam ve tanımı farklılıklar göstermektedir (Doğan ve Tütüncü, 2003: 1).

Amerikan Pazarlama Birliği hizmeti, "satışa sunulan ya da malların satışıyla birlikte sağlanan eylemler, yararlar ya da doygunluklardır" şeklinde tanımlamaktadır (Brown vd., 1993:128) Bu tanımda dikkat çeken eksiklik fiziksel mallar ile hizmetleri 
yeterince ayıramamasıdır. Çünkü fiziksel mallar da fayda veya tatmin sağlamak amacıyla üretilip satılmaktadır (Ersöz vd., 2009:20). Bu eksiklikten dolayı sonraki yıllarda yapılan tanımda hizmet; bir malın satışa bağlı olmaksızın nihai tüketicilere ve işletmelere pazarlandığında istek ve ihtiyaç doygunluğu sağlayan ve bağımsız olarak tanımlanabilen eylemlerdir (Filiz vd., 2010:62).

Philip Kotler ve Gary Armstrong'un yapmış oldukları tanımda daha kapsamlı bir yaklaşım dikkati çekmekte olup, birinin diğerine sunduğu, esas olarak dokunulamayan ve herhangi fiziksel bir şeye sahip olmayla sonuçlanmayan faaliyet ya da faydadır. Üretilmesi fiziksel ürüne bağlı olabilir ya da olmayabilir (Kotler ve Armstrong, 2011: 298).

Hizmet, tüketici istek ve ihtiyaçlarını karşılamak amacıyla üretilen ve fiziksel ürünler gibi mevcudiyeti olmayan ürünlerdir (Çelik, 2011: 435). Bu bağlamda hizmet soyut bir kavramdir. Ayrica, envanteri tutulamamakta, depolanamamakta, standartlaştırılamamakta, üretildiği anda sahipliği olmakta, görsellik, nesnellik ve mülkiyet ilişkisi bulunmamaktadır (Eleren ve Kılıç, 2007: 237).

Sonuç olarak, hizmet kavramını açıklama üzerine yapılan çalışmaların sonuçlarından elde edilen ortak kanı kavramı tanımlamanın zor ve karmaşık olmasıdır. Bu bağlamda hizmet kavramını açıklamaya yönelik çok farklı tanım ve düşünce olsa da bütün yazarların üzerinde anlaştığı ortak nokta, hizmetin üretildiği anda tüketilebilen, üretim esnasında karşılıklı iletişimin olduğu ve öncesinde kontrol yapabilme olasılığının olmadığı soyut kavram olduğudur (Heizer ve Render, 2011: 52).

\subsection{Kalite Kavramı}

Kalite kavramı kullanım amacına göre farklı anlamları ifade edebilmektedir. Tüketici açısından kalite pahalı, lüks, az bulunan, üstün nitelikte, dayanıklı gibi anlamlarda kullanılabilirken işletmelere kişilere göre ise, standartlara uygunluk ile özdeş olan bir kavramdır (Kayral, 2014: 25). Ayrıca kalite kavramı, işletmeler tarafından tercih edilen önemli stratejik rekabet aracı iken, tüketiciler için marka veya ürün tercihlerini belirleyen temel unsurlardan biri olmaktadır (Naik, ve Srinivasan, 2015: 28). Bu bağlamda işletmelerin sundukları ürünün kalitesini arttırması, kusurlu ürün sayısını en aza indirmesine yardımcı olmaktadır. Böylece kalite, işletmelerin verimliliklerini arttırmakta ve rekabet üstünlüğü sağlayarak pazar paylarını artırmalarına yardımcı olmaktadır (Atan vd., 2010: 3).

Kotler ve Armstrong, kaliteyi performans ve uygunluk olmak üzere iki bölümde tanımlamıştır. Performans kalitesi ürünün işlevini yerine getirdiği seviyeyi göstermektedir. Uygunluk kalitesi ise, ürünün tasarımına uygunluk derecesini göstermektedir (Kotler ve Armstrong, 2011: 367).

Kalite; tüketiciye uygunluk, şartlara uygunluk, mal ya da hizmetin ihtiyacı karşılayabilme yeteneklerini ortaya koyan özelliklerin bütünü, mükemmellik derecesi, kullanıma uygunluk, amaca uygunluk, hatasız ve kusursuz olmak ve tüketiciyi tatmin etmek şeklinde tanımlanabilmektedir (Hoyle, 2007: 9). Kalitenin çeşitli boyutları, mal ve hizmette performans, güvenilirlik, dayanıklılık, estetiklik ve değerdir. Özetle kalite, tüketici istek ve beklentilerine uyumlu olmaktır (Savaş ve Kesmez, 2014: 2). 
Kütüphanecilik alanında ise kalite, ilk kez F. W. Lancaster' in, 1969 yılında, Index Medicus veri tabanındaki taramaların başarısına ilişkin kavramsal bir ifade olarak kullanılmıştır. Kalite kavramı, özellikle 90'ların sonunda ve 2000'li yıllarda önemini artırarak, kütüphanelerde kalite çalışmalarının hız kazanmasına sebep olmuştur (Güzel ve Kotan, 2013: 12).

\subsection{Hizmet Kalitesi}

Hizmet kalitesi, sunulan hizmetin tüketici beklentilerini karşılama ve tatmin seviyesinin bir göstergesidir. Bir başka ifadeyle hizmet kalitesi, işletmenin tüketici beklentilerini karşlayabilme ve geçebilme yeteneğidir (Wang ve Shieh, 2006: 195). Hizmet kalitesinde önemli olan tüketicinin algıladığı kalitedir. Bu bağlamda hizmet kalitesinin, kalitenin tüketici tarafından algılanan performans düzeyi ya da hizmetin tüketiciyi tatmin etme seviyesi olduğu belirtilebilir (Zengin ve Erdal, 2005: 4).

Kalite gibi hizmet kalitesinin de çok boyutlu bir kavram olması, kesin tanımının yapılmasını zorlaştırmaktadır. Hizmet kalitesini; müşteri beklentilerini karşılayabilme, ihtiyaçlarını tanımlayabilme derecesi olarak ifade edilebilir (Dursun vd., 2014: 97). Başka bir tanımda hizmet kalitesi, performans ve ideal standartlar arasındaki kıyaslama olarak tanımlanmaktadır (Kang, 2006: 39). Hizmet kalitesi, sunulan hizmetin tüketici istek ve beklentisini karşılama ve geçme düzeyi olarak da tanımlanmaktadır (Moss, 2007: 5).

Yukarıda belirtilen tanımlardan hareketle, hizmet kalitesi, tüketicinin hizmeti satın aldıktan sonra hizmetten sağladığı faydanın kendisinde oluşturduğu haz ve duygu olup, söz konusu hizmetten tatmin derecesini ifade etmektedir (Negi, 2009: 33). Dolayısıyla hizmet kalitesi kavramının bileşenlerini, alıcının ihtiyaç ve beklentilerini karşılamak için uygun özelliklere ve niteliklere sahip olması oluşturmaktadır (Aydın, 2007: 263).

Tüketicinin aldığı hizmetin kalitesinin belirlemesi soyut bir süreçtir. Yani alıcı somut bir ürün hakkındaki görüşünü belirttiği gibi rahat olamamaktadır (Kristensen ve Eskildsen, 2012: 49). Bu yüzden hizmet kalitesini ölçmek için çeşitli yöntem ve modeller geliştirilmiştir.

\subsection{Hizmet Kalitesi Modelleri}

Soyut bir kavram olan hizmet kalitesini daha iyi açıklayabilmek için bazı kavramların tanımlanması gerekmektedir. Hizmet, kalite, hizmet kalitesi gibi konularla ilgili çalışma yapmış araştırmacılar tarafından hizmet kalitesinin modellerini oluşturmak amacıyla bazı önermeler oluşturulmuş ve bunlar doğrultusunda farklı modeller ileri sürülmüştür (Kavak vd., 2013: 84).

Hizmet kalitesini ölçmek amacıyla geliştirilen bu modeller daha sonra yapılan çalışmalara hizmet kalitesi ölçümünün nasıl yapılabileceği noktasında farklı yaklaşımların oluşmasına yol açmaktadır (Mbise ve Tuninga, 2013: 104). Hizmet kalitesinin ölçümüne esas olabilecek beş değişik hizmet kalitesi modelinin araştırmacılar tarafından geliştirildiği görülmektedir. Bu modellerden ilkini Grönroos (1983)' “hizmet kalitesi modeli” oluşturur. Bu modeli sırasıyla Lehtinen ve Lehtinen (1983), Normann (1984), Kano (1984) ve Parasuraman ve diğerleri (1985) tarafından 
geliştirilen "algılanan hizmet kalitesi (Boşluk Modeli)" modelleri takip etmektedir. Araştırmanın amacı doğrultusunda diğer modellerin incelenmesine gerek olmadığı düşünülüp sadece Parasuraman, Zeithalm ve Berry (1988) Hizmet Kalite Modeli incelenecektir.

Parasuraman, Zeithalm ve Berry tarafından geliştirilen bu model "Kavramsal Hizmet Kalitesi Modeli" olarak adlandırılmış ve hizmet kalitesi araştırmalarında en fazla tercih edilen modeldir (Untaru vd., 2015: 85). Model beklenen ve algilanan hizmet kalitesi olmak üzere iki temel bölümden oluşmaktadır. "Beklenen hizmet kalitesi, tüketicilerin aldıkları hizmetten arzuladıklarını veya isteklerini ifade ederken, alg1lanan hizmet kalitesi ise, müşterinin hizmet almadan önceki beklentileri ile hizmet aldıktan sonraki deneyimlerinin karşılaştırması" olarak tanımlanmaktadır (Zeithaml ve Bitner, 2000: 53)

Parasuraman, Zeithalm ve Berry bu modeli oluşturmak için çalışmaya başladıklarında değişik sektörlerden dört firmayı incelemişlerdir. Hizmet alanındaki sektörlere ait birçok özelliği inceleyerek her sektör için geçerli olabilecek ve tüketicilerin kalite algılarını ölçebilecek uygun bir model ortaya çıkarmayı amaçlamışlardır (Mbise ve Tuninga, 2013: 107). Tüketicilerin hizmet kalitesini değerlendirirken bazı boyutların olduğunu ortaya çıkarmışlardır. Araştırmacıların çalışmaları sonucunda sundukları 10 hizmet kalitesi boyutunu şu şekilde tanımlamışlardır (Parasuraman vd., 1985: 43-45);

- Fiziksel Özellikler: Hizmetin sunumu esnasında kullanılan bina, araç, malzeme gibi ekipmanlar fiziksel özellikleri olarak tanımlanmaktadır. Ayrıca hizmet sunan personelin fiziksel görünüşü ve diğer hizmet alan personeli kapsamaktadır.

- Güvenilirlik: Hizmetin doğru, dürüst ve etik değerlere uygun ve tüketiciye güvenilir şekilde sunulmasını ifade etmektedir. İşletmenin verdiği sözü zamanında, tutarlı ve belirtilen şartlara uygun yerine getirmesidir.

- Heveslilik: Çalışanların hizmet verme konusunda hazır ve istekli olmaları ile açıklanmaktadır. Bu boyut, müşteriye anında hizmet sunma, müşteriye yardımcı olma ve zamanında onlara geri dönüş yapabilme faaliyetleri kapsamaktadir.

- Yeterlilik: Hizmet sunanların gerekli tecrübe, bilgi, birikim ve beceriler sahip olması olarak açıklanmaktadır. Diğer bir ifadeyle çalışanların uzmanlık, yetenek, eğitim ve yeniklikçi gibi özellikleri içermektedir.

- Nezaket: Hizmet sunan personelin tüketiciye kibar, nazik saygılı ve samimi olmasıdır. Çalışanların tüketici taleplerine karşı dinleyen ve çözüm bulmaya çalışması bu boyutun kapsamına girmektedir.

- İnanılırlık: Hizmet sunum sürecinde tüketicilerin çıkarlarına önem verildiğinin hissettirilip, güvenin kazanılmasıdır.

- Güven: Sunulan hizmetlerin işletme tarafından algılanan risk seviyesinin en az seviyeye indirilmesi olarak tanımlanmaktadır. Tüketicilerin kişisel bilgilerinin gizliliğine sayg1, finans bilgilerinin güvenilirliği ve ahlaki değerlere sahip personelin çalıştırılmasını kapsamaktadır. 
- Ulaşılabilirlik: Hizmete ulaşmak için gerekli fiziki ortamların oluşturulması ve iletişim araç ve teknikleriyle hizmete ulaşımının kolaylaştırılmasını kapsamaktadir.

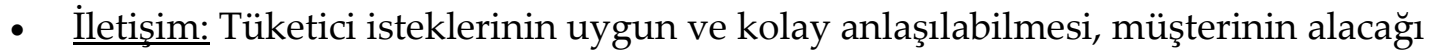
hizmet hakkındaki bilgilerin kolay, anlaşılır ve açık şekilde anlatılması gibi hususları içermektedir.

- Müş̧teriyi Anlama: Müşterinin istek, ihtiyaç ve problemlerinin anlaşılması ve müşterinin hedeflerine ulaşmasını kapsamaktadır.

\subsection{Servqual Hizmet Kalitesi Ölçeği}

Hizmet kalitesini ölçebilmek amacıyla çeşitli ölçekler geliştirilmiştir. Bunlar arasında akademik çalışmalarda yaygın olarak kullanılan ölçek 1983-1990 yılları arasında Parasuraman, Zeithalm ve Berry tarafından geliştirilen Servqual Yöntemi'dir (Wang vd., 2015: 36). Bu yöntem, beklenen ve alg1lanan kalitenin tüketiciler tarafından değerlendirilmesi esasına dayanan anket tekniğidir. Bu ölçek temel olarak, müşteri memnuniyeti ve tatmininin "algılamaların beklentiden farklılaşmasının bir fonksiyonu" olduğunu ileri sürmektedir (İzci ve Saydam, 2013: 202).

Başlangıçta, hizmet kalitesini on belirleyici olarak tespit eden Parasuraman, Zeithalm ve Berry (1985), daha sonra belirleyicileri; fiziksel özellikler, güvenirlik, heveslilik, güven ve empati olmak üzere beş boyutta toplamışlardır. Bu boyutlar çerçevesinde Parasuraman, Zeithaml ve Berry (1988) işletmenin sunduğu hizmet kalitesi ile ilgili olarak müşteri ve işletme algılamaları arasındaki farklılıklara önem vermişlerdir (Kristensen ve Eskildsen, 2012: 51). Yazarlar, müşterinin algılamaları ile beklentileri arasındaki farklılıkları ölçerek hizmet kalitesinin tespit edilebileceğini ileri sürmüşlerdir. Eğer algılanan kalite beklenen kaliteden büyükse yüksek hizmet kalitesi, eğer küçükçe düşük hizmet kalitesi olarak değerlendirileceğini belirtmişleridir (Yıldız, 2009: 1216). Bu ölçekte "kaliteli" olarak tanımlanabilecek hizmette bulunması gereken özellikler araştırılmış ve 22 ifade belirlenmiştir. Tüketicilerin hizmeti almadan önce belirlenen bu ifadeler hakkında çeşitli beklentileri bulunmakta, hizmeti aldıktan sonra, beklentileri ile aldıkları hizmeti karşılaştırmaktadırlar (Naik ve Srinivasan, 2015: 29). Alınan hizmet beklentileri karşılıyor ise hizmetin kaliteli olduğu, eğer hizmet beklentileri karşılamıyorsa arada bir boşluk olduğu sonucuna varılmaktadır. Bunun sonucunda tatminsizlik ortaya çıkmaktadır. Bu nedenle Servqual ölçeği "Boşluk" modeli olarak da adlandırılmaktadır (Öztürk, 2013: 189).

Servqual ölçeğinde beş tane boşluğun olduğu tespit edilmiştir. Bu boşluklardan ilk dördü hizmeti sunan işletmeyle ilgili beşincisi ise müşterinin kendisiyle ilgilidir. Bu boşluklar şu şekildedir (Hemedoğlu, 2012: 29);

- Boşluk1: Tüketici beklentilerinin işletme tarafından doğru algılanamaması,

- Boşluk2: Oluşturulan hizmet kalitesi standartlarının tüketici beklentilerini karşılamaması,

- Boşl1k3: Gerçekleşen hizmet sunumunun oluşturulan hizmet kalitesi standartlarına uymaması,

- Boşluk4: Taahhüt edilen sunum ile gerçekleşen sunum arasındaki tutarsızlık,

- Boşluk5: Algilanan ve beklenen hizmet arasındaki farktır. 
Boşluk analizinde, farklı sektörlerde sunulan hizmetlerin tatmin edici olmasını engelleyen ve yukarıda sıralanan söz konusu boşlukların oluşmaması ya da oluşmuş ise kapatılması için uygulanabilecek genel anlayış ve çözümler ayrıntılarıyla ele alınmaktadır (Taşkın vd.,2010: 14). Bu nedenle Servqual ölçeği, hizmet kalitesinin ölçümü konusunda çok kullanılan bir modeldir.

\subsection{Kütüphane Hizmet Kalitesi Araştırmaları}

İyi organize olmuş, çağdaş bina ve tesise sahip, çalışanlarının bilgi ve becerilerinin yüksek seviyede olan bir üniversite kütüphanesi, bilimsel açıdan hayati öne taşımaktadır. Üniversite kütüphanelerinin fonksiyon ve amaçlarının, üniversitenin amaç, işlev ve farkındalığına katkı sağlaması gerekmektedir (Ladhari ve Morales, 2008: 359). Bu bağlamda üniversite kütüphanelerinin; akademisyen ve öğrencilerin bilgi kaynaklarından etkin bir şekilde yararlanması için gerekli hizmetlerin sunulması, farklı bilimsel alanlar için okuma ve çalışma alanlarının oluşturulması, kütüphane personeli için eğitim programlarının uygulanması, uygun ve yeterli arşivlemenin yapılması, nadir eserlerin korunması için gerekli tedbirlerin alınması gibi işlevleri bulunmaktadır Karahan ve Kayabaşı, 2013: 188).

Servqual ölçeği, gelişmesine ve eksikliklerinin giderilmesinin sonucu olarak kütüphanecilik alanındaki çalışmalarda kullanılması artış göstermektedir (Zakaria vd., 2011: 267). Servqual ölçeğinin kütüphanecilik alanında kullanıldığı çalışmaların bazıları aşağıda sunulmaktadır.

Herbert (1994), Kanada'da halk kütüphaneleri tarafından sağlanan kütüphaneler arası işbirliğinde hizmet kalitesini incelemiştir. Çalışmasında birçok ölçüm kullanmıştır. Bu ölçümlerde araştırmaya katılanlardan kütüphane kullanıcısı rolünü üstlenmeleri, kütüphaneye giderek görevlilerden bulamadıkları kitabı sağlamak için yardım istemeleri ve bu hizmet deneyimlerini kaydetmeleri istenmiştir. Kütüphanelerde yayınların dönüşüm süreleri hesaplanmıştır. Servqual anketleri ise hizmet kalitesini müşterilerin bakış açısından ölçmek için kullanılmıştır. Yazar araştırmanın sonucunda Servqual ifadelerinde bazı değişiklikler yapılmıştır.

Cook ve Thompson (2000) ise, Servqual ölçeğinin kütüphanelere uygulanmasından çıan skorların güvenilirliğini ve geçerliliğini araştırmışlardır. Yazarlar, Servqual'in kütüphanelerde kullanımına ilişkin olarak iki araştırma sorusu belirlemişlerdir. İlk olarak farklı zaman ölçütleri ve değişik gruplar arasındaki sonuçları güvenirlik durumunu incelemişler ve daha sonra Servqual boyutunun teoride belirlenen faktör yapısını sağlayıp sağlamadığını araştırmışlardır. Araştırma sonucunda, Cook ve Thompson Servqual'in akademik kütüphanelerde yapılan çalışmalarını gözden geçirdiklerinde modelinin beş boyutundan üçünün sürekli olarak kütüphanelerde ortaya çıtığını görmüşlerdir. Ayrıca sonuçların güvenilirlik düzeylerini zamana ve uygulanan gruba göre değiştiğini tespit etmişlerdir.

Hernon ve Calvert (2005) çalışmalarında, Servqual ölçeğini üniversite kütüphanelerinin sunduğu elektronik hizmet kalitesi açısından güvenilirliğini ve geçerliliğini incelemişlerdir. Araştırmalarının sonucunda elektronik hizmet kalitesinin boyutları olarak, bağlantı, doğruluk, kaynak yeterliliği, güvenilirlik, teknolojik destek, 
güven, erişim kolaylığı, esneklik ve kişiselleştirme olmak üzere dokuz boyut olduğunu tespit etmişler ve mevcut ölçeğin yeterli olmadığını belirmişlerdir. Araştırmanın sonucunda LibQUAL ölçeğinin kütüphane hizmet kalitesi ölçümünde daha etkili olduğunu belirtmişlerdir.

Güzel ve Kotan (2013) yaptıkları çalışmasında Atatürk Üniversitesi Kütüphanesi'nde sağlanan hizmet kalitesi düzeyinin ortaya konularak müşterilerin beklentilerini ve algılamalarını tespit etmeyi amaçlamışlardır. Yazarlar Servqual ölçeğini kullanmışlar ve ölçeğin kütüphane hizmetlerinin ölçülmesinde uygun olduğu sonucuna varmışlardır.

\section{HIZMET KALITTESININN SERVQUAL ÖLÇEĞİ İLE ÖLÇÜLMESİ İLE İLGİLİ BİR ARAŞTIRMA}

\subsection{Araştırmanın Amacı, Kapsamı ve Kısıtları}

$\mathrm{Bu}$ araştırmanın amacı, Uşak Üniversitesi Merkez Kütüphanesi'nin öğrencilere sunduğu hizmet kalitesinin öğrenci beklentilerini karşılama derecesini "Servqual Hizmet Kalitesi Ölçeği" ile belirlemek ve elde edilen verilerin değerlendirilmesi neticesinde Merkez Kütüphanenin hizmet kalitesini iyileştirme gayretlerine katkı sağlamaktır.

Araştırmanın kapsamına, Merkez Kütüphane Uşak Üniversitesi Bir Eylül Kampüsü'nde bulunduğu için yerleşke içerisinde bulunan enstitü (Fen ve Sosyal Bilimler Enstitüleri), fakülte (İktisadi ve İdari Bilimler Fakültesi, Eğitim Fakültesi, Fen Edebiyat Fakültesi, Mühendislik Fakültesi, İslami İlimler Fakültesi, Ziraat ve Doğa Bilimleri Fakültesi, İletişim Fakültesi ve Spor Bilimleri Fakültesi), yüksekokul (Uygulamalı Bilimler Yüksekokulu) ve meslek yüksekokullardaki (Adalet Meslek Yüksekokulu, Teknik Bilimler Meslek Yüksekokulu, Sosyal Bilimler Meslek Yüksekokulu) öğrencileri alınmıştır. Diğer yerleşkelerdeki yüksekokul ve meslek yüksekokulları araştırma kapsamının dışında tutulmuştur. Bu nedenle araştırmanın sonucu bütün üniversite kütüphanelerine genellenemez.

\subsection{Araştırmanın Modeli}

Araştırmada hizmet kalitesinin ölçümünde Parasuraman, Zeithalm ve Berry (1985) tarafından geliştirilen "Servqual Hizmet Kalitesi Ölçeği" kullanılmıştır. Kullanılan değişkenler genel olarak ikiye ayrılabilir: Kullanıcıların kütüphane hizmetlerinden beklentileri birinci grup değişkenleri ve ikinci grup değişkenleri ise, kütüphanenin sunmuş olduğu hizmetin kalitesi açısından kullanıcıların algıları oluşturmaktadır. Bu değişkenlere bağlı olarak hesaplanan ve algılanan hizmet kalitesi skoru olarak Servqual skoru da bağımlı bir değişken olarak çalışmada kullanılmıştır. Ayrıca modelde demografik, ekonomik ve kütüphane kullanma değişkenlerinin de beklenen ve algılanan hizmet kaliteleri ile arasında ilişkili olabileceği varsayılmaktadır. Araştırmanın modeli Şekil 1'de verilmiştir. 


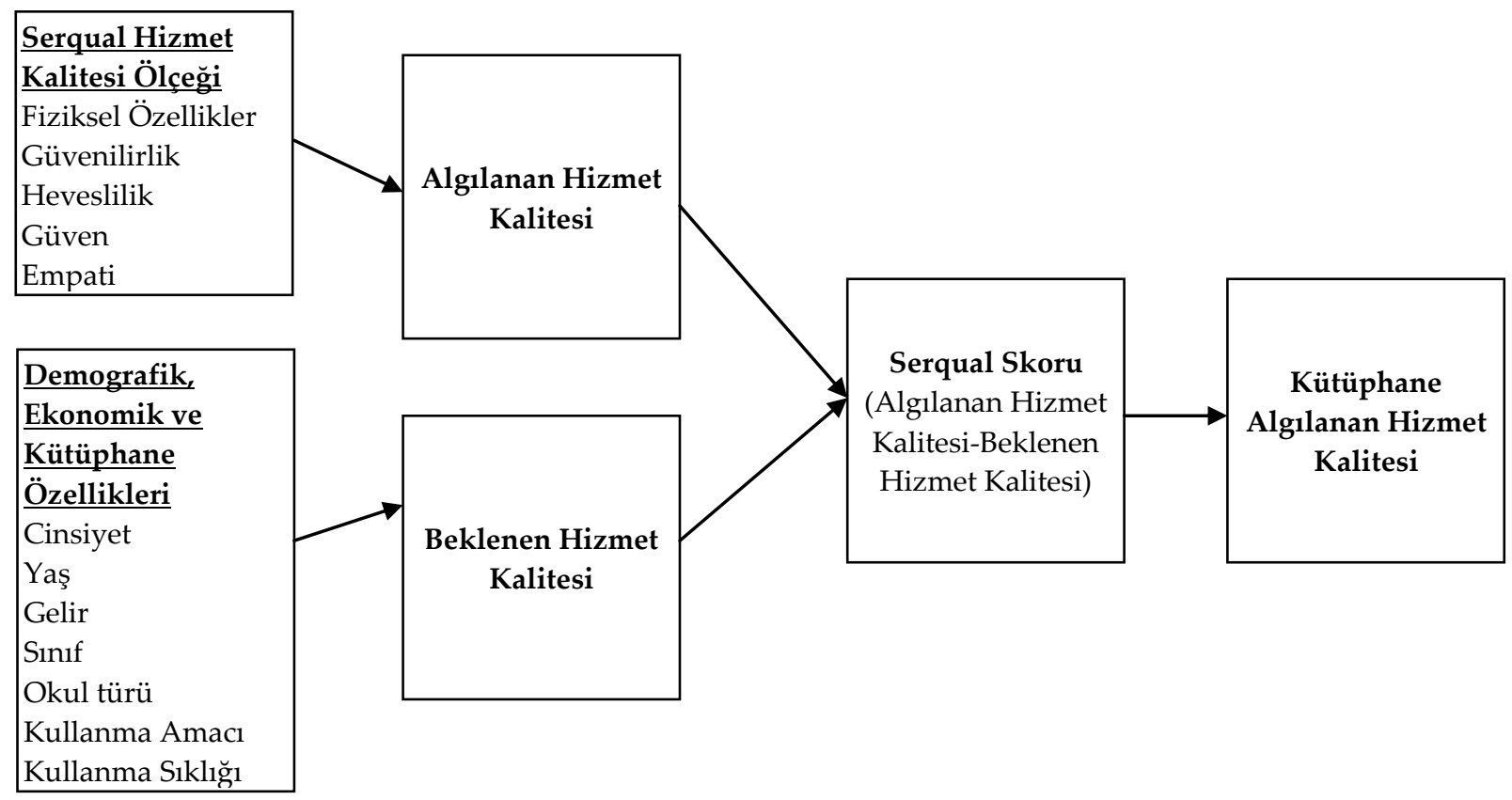

Şekil 1. Araştırmanın Modeli

\subsection{Araştırmanın Hipotezleri}

Araştırmanın amacı ve modeli doğrultusunda aşağıdaki hipotezler geliştirilmiştir.

- $H_{1}$ : Uşak Üniversitesi Kütüphanesinin sahip olduğu fiziksel özellik açısından beklenen hizmet kalitesi ile algılanan hizmet kalitesi arasında farklılık vardır.

- $\quad H_{2}$ : Uşak Üniversitesi Kütüphanesine duyulan güvenilirlik açısından beklenen hizmet kalitesi ile algılanan hizmet kalitesi arasında farklılık vardır.

- $H_{3}$ : Uşak Üniversitesi Kütüphanesi çalışanlarının hevesliliği açısından beklenen hizmet kalitesi ile algılanan hizmet kalitesi arasında farklılık vardır.

- $\quad H_{4}$ : Uşak Üniversitesi Kütüphanesine duyulan güven bakımından beklenen hizmet kalitesi ile algılanan hizmet kalitesi arasında farklılık vardır.

- $\quad H_{5}$ : Uşak Üniversitesi Kütüphanesi çalışanlarının kurduğu empati açısından beklenen hizmet kalitesi ile algılanan hizmet kalitesi arasında farklılık vardır.

\subsection{Araştırmanın Metodolojisi}

\subsection{1.Örnekleme Süreci}

Araştırmanın kapsamı doğrultusunda Uşak Üniversitesi Bir Eylül Kampusu'ndaki enstitü, fakülte, yüksekokul ve meslek yüksekokullardaki öğrenciler alınmış ve ana kütle toplam 16932 öğrenciden oluşmuş olması örneklemin bu sayıya göre alınmasını süre ve maliyet bakımından zorlaştırmaktadır. Bu nedenle \%95 güven aralığında \%5 hata payı ile örneklem büyüklüğü 384 olarak belirlenmiştir. Hatalı ve eksik doldurulması muhtemel anket olabileceği düşünülerek toplam 400 anket uygulanmıştır. Aşağıdaki tabloda okulların mevcut öğrenci sayıları ve uygulanan anketlerin okullara göre dağılımları Tablo 1'de gösterilmektedir. 
Tablo 1. Anket Uygulanan Okulların Öğrenci ve Uygulanan Anket Sayıları

\begin{tabular}{|l|c|c|c|}
\hline Okul Şekli & Öğrenci Sayısı & $\begin{array}{c}\text { Uygulanan Anket } \\
\text { Sayısı }\end{array}$ & $\begin{array}{c}\text { Değerlendirmeye } \\
\text { Alınan Anket Sayısı }\end{array}$ \\
\hline Enstitü & 1708 & 40 & 36 \\
\hline Fakülte & 11592 & 274 & 263 \\
\hline Yüksekokul & 1027 & 24 & 23 \\
\hline Meslek Yüksekokulu & 2605 & 62 & 56 \\
\hline TOPLAM & $\mathbf{1 6 9 3 2}$ & $\mathbf{4 0 0}$ & $\mathbf{3 7 8}$ \\
\hline
\end{tabular}

Anket çalışması 06-20 Nisan 2015 tarihleri arasında yapılmıştır. Toplam 400 anket uygulanmış, eksik ve hatalı doldurulan anketlerin elenmesi sonucu 378 anket değerlemeye alınmıştır.

\subsection{2. Ön Çalışma}

Araştırma için kesin anket formu hazırlanıp veri toplanmasına geçilmeden önce araştırma örneğini temsil edecek şekilde seçilen 20 öğrenci ile ön anket çalışması yapılmıştır. $\mathrm{Bu}$ kişilere Uşak Üniversitesi Merkez Kütüphanesinin hizmetleri hakkında beklentileri düzeylerini belirlemek için sorular sorulmuştur. İkinci aşamada ise kütüphane hizmetlerini algılama düzeyleri için çeşitli ifadeler sorulmuştur. Beklenti ve algılamalar ile ilgili ifadeleri değerlendirmeleri sonucunda anlaşılmayan, yanlış anlaşılan ve karıştırılan ifadeleri belirtmeleri istenmiştir. Anket formu bu değerlendirmelerden sonra tekrar test edilmiş ve forma son şekli verilmiştir.

\subsubsection{Veri Toplama Yöntem ve Aracı}

Araştırmada veriler, kapalı uçlu soruların yer aldığı anket yöntemi kullanılarak toplanmıştır. Anket formunda 3 grup soru yer almıştır. 1. grupta cevaplayıcıların üniversite kütüphanesinden beklentilerini belirlemek amacıyla çeşitli ifadeler sunulmuştur. 2. grup demografik, ekonomik ve kütüphane kullanma amaç ve sıklığı sorularından oluşmuş ve 3 . grup algılanan hizmet kalitesini ölçmeye yönelik yargılarını tespit etmek amacıyla hazırlanmıştır. Modelde yer alan beklenen ve algılanan hizmet kalitesi değişkenleri Servqual Hizmet Kalitesi Ölçeğinden yararlanılarak hazırlanmıştır. Bu ölçeğin fiziksel özellikler bölümüne yapılan literatür araştırmasının sonucunda altı yeni ifade ilave edilmiştir. Sevqual skoru değişkeni ise algılanan hizmet kalitesi ortalamalarından beklenen hizmet kalitesi ortalamalarının çıkarılması ile elde edilmiştir. Cevaplayıcıların beklenen ve algılanan hizmet kalitesi ile ilgili yargılara katılma derecesi 5'li likert ölçeği (5=Tamamen katılıyorum, 1=Kesinlikle katılmıyorum) ile ölçülmüştür.

Verilerin analizinde SPSS 18.0 paket istatistik programı kullanılmıştır. Araştırmada ortalamalar, standart sapma, frekans dağılımları, Servqual skoru, Kendall korelasyonu ve eşleştirilmiş örneklemler $\mathrm{t}$ testi analizleri yapılmıştır.

\subsection{Verilerin Analizi}

\subsubsection{Cevaplayıcıların Demografik ve Ekonomik Özellikler}

Tablo 2'de ankete katılan cevaplayıcıların demografik, ekonomik ve kütüphane kullanma özellikleri gösterilmiştir.

Ankete katılanların; \%57,7'si kız ve \%42,3'üu erkek öğrencidir. Çoğunluğu 19-20 yaş grubunda yer almakta (\% 52,9) ve \%47'sinin aylık 301-600 TL arasında harçlı̆ga sahip olmaktadır. Eğitim görülen okul açısından cevaplayıcıların \%69,6'sı fakültelerde ve birinci 
sınıfta $(\% 57,9)$ öğrenim görmektedir. Cevaplayıcıların büyük çoğunluğu kütüphaneden ders çalışmak $(\% 40)$ ve araştırma yapmak $(\% 24,3)$ için yararlandıklarını ve haftanın en az iki günü $(\% 26,7)$ kütüphaneye gittiklerini belirtmişlerdir.

Tablo 2. Cevaplayıcıların Demografik, Ekonomik ve Kütüphane Kullanma Özellikleri

\begin{tabular}{|l|c|c|l|c|c|}
\hline Cinsiyet & Frekans & Yüzde & Yaş & Frekans & Yüzde \\
\hline Kız & 218 & 57,7 & 18 ve altı & 25 & 6,6 \\
\hline Erkek & 160 & 42,3 & 19 & 96 & 25,4 \\
\hline Gelir (TL) & Frekans & Yüzde & 20 & 104 & 27,5 \\
\hline $0-300$ & 99 & 26,2 & 21 & 77 & 20,4 \\
\hline $301-600$ & 178 & 47,0 & 22 & 35 & 9,3 \\
\hline $601-900$ & 67 & 17,8 & 23 & 29 & 7,7 \\
\hline $901-1200$ & 23 & 6,1 & 24 ve üzeri & 12 & 3,1 \\
\hline 1201 ve üzeri & 11 & 2,9 & Eğitim Gördüğü Okul & Frekans & Yüzde \\
\hline Eğitim Gördüğü Sınıf & Frekans & Yüzde & Enstitü & 36 & 9,5 \\
\hline Hazırlık & 9 & 2,4 & Fakülte & 263 & 69,6 \\
\hline Birinci Sınıf & 219 & 57,9 & Yüksekokul & 23 & 6,1 \\
\hline İkinci Sınıf & 77 & 20,4 & Meslek Yüksek Okulu & 56 & 14,8 \\
\hline Üçüncü Sınıf & 48 & 12,7 & $\begin{array}{l}\text { Kütüphane Kullanma } \\
\text { Sıklı̆̆1 }\end{array}$ & Frekans & Yüzde \\
\hline Dördüncü Sınıf & 25 & 6,6 & Haftanın hergünü & 45 & 11,9 \\
\hline $\begin{array}{l}\text { Kütüphane Kullanma } \\
\text { Amacı }\end{array}$ & Frekans & Yüzde & Haftada Bir Gün & 57 & 15,1 \\
\hline Ders çalışmak & 153 & 40,5 & Haftada İki Gün & 101 & 26,7 \\
\hline $\begin{array}{l}\text { İnternet hizmetinden } \\
\text { yararlanmak }\end{array}$ & 74 & 19,6 & Haftada Üç Gün & 94 & 24,9 \\
\hline Araştırma yapmak & 92 & 24,3 & Haftada Dört Gün & 43 & 11,4 \\
\hline Kitap, gazete vb. okumak & 42 & 11,1 & Haftada Beş Gün & 26 & 6,8 \\
\hline $\begin{array}{l}\text { Kantin hizmetinden } \\
\text { yararlanmak }\end{array}$ & 17 & 4,5 & Haftada Altı Gün & 12 & 3,2 \\
\hline TOPLAM & $\mathbf{3 7 8}$ & $\mathbf{1 0 0}$ & TOPLAM & 378 & $\mathbf{1 0 0}$ \\
\hline
\end{tabular}

\subsubsection{Araştırma Ölçeğinin Servqual Skorları}

Araştırmanın ölçüm güvenilirliğini test etmek için iç tutarlılık değerlendirmesini belirlemek için Cronbach $\alpha$ katsayısı yönteminden yararlanılmıştır. Güvenilirlik analizi sonucunda beklenen ve algılanan hizmet kalitesinde güvenilir ve geçerli olmayan soruya rastlanılmamıştır. Beklenen kütüphane hizmet kalitesinin 28 ifadenin Cronbach's Alpha değeri 0,959 ve algılanan kütüphane hizmet kalitesinin Cronbach's Alpha değeri 0,946 çıkmıştır. Değerler 0,81 'den daha yüksek değerlere sahip olduğundan dolayı her iki ölçekteki soruların içsel uyumunun yüksek olduğu söylenebilir (İslamoğlu ve Alnıaçık, 2013: 278). Tablo 3'de Algilanan ve beklenen hizmet kalitesine ait ortalama ve standart sapmalarla birlikte Servqual skorları görülmektedir.

Tablo 3'de görüldüğü üzere algılanan hizmet kalitesinde kütüphane binasının modern bir görünüşe sahip olması $(4,1909)$ ve fiziksel imkanları (mobilya, aydınlatma, dekor vb.) görsel açıdan çekici olması $(4,1733)$ öne çıkan değişkenleri oluşturmaktadır. Beklenen hizmet kalitesinde ise, modern araç, gereç ve donanıma sahip olması $(4,5185)$ ve çalışanların düzgün ve temiz olması $(4,4241)$ öne çıkmaktadır. Kütüphanenin fiziksel özellikler için beklenti ve alg1 ortalamaları ile hesaplanan servqual skoru -0,4331 olarak bulunmuştur. $\mathrm{Bu}$ 
sonuçla, kütüphane fiziksel özelliklerinin öğrencilerin beklentilerini karşılamadığ söylenebilir.

Tablo 3. Algilanan ve Beklenen Hizmet Kalitesi Değerlerinin Ortalama, Standart Sapma ve SERVQUAL Skorları

\begin{tabular}{|c|c|c|c|c|c|}
\hline \multirow{2}{*}{ HİZMET KALİTESİ İFADELERİ } & \multicolumn{2}{|c|}{$\begin{array}{l}\text { Algılanan Değerler } \\
(\alpha=0,946)\end{array}$} & \multicolumn{2}{|c|}{$\begin{array}{l}\text { Beklenen Değerler } \\
\qquad(\alpha=0,959)\end{array}$} & \multirow{2}{*}{$\begin{array}{l}\text { SERVQUAL } \\
\text { SKORU }\end{array}$} \\
\hline & $\begin{array}{l}\text { Aritmetik } \\
\text { Ortalama }\end{array}$ & $\begin{array}{l}\text { Standart } \\
\text { Sapma }\end{array}$ & $\begin{array}{l}\text { Aritmetik } \\
\text { Ortalama }\end{array}$ & $\begin{array}{l}\text { Standart } \\
\text { Sapma }\end{array}$ & \\
\hline \multicolumn{6}{|l|}{ FİZIKSEL ÖZELLİKLER } \\
\hline $\begin{array}{l}\text { Modern araç, gereç ve donanıma sahip } \\
\text { olması }\end{array}$ & 4,1020 & 0,9746 & 4,5185 & 0,7628 & $-0,4165$ \\
\hline $\begin{array}{l}\text { Fiziksel imkânları (mobilya, } \\
\text { aydınlatma, dekor vb.) görsel açıdan } \\
\text { çekici olması }\end{array}$ & 4,1733 & 0,8970 & 4,3048 & 0,8886 & $-0,1315$ \\
\hline $\begin{array}{l}\text { Çalışanların temiz ve düzgün } \\
\text { görünüşlü olması }\end{array}$ & 4,1268 & 0,9472 & 4,4241 & 0,8045 & $-0,2973$ \\
\hline $\begin{array}{l}\text { Hizmet verilirken kullanılan } \\
\text { malzemelerin modern ve kullanışlı } \\
\text { olması }\end{array}$ & 4,0743 & 0,8797 & 4,4131 & 0,8265 & $-0,3388$ \\
\hline $\begin{array}{l}\text { Kütüphane binasının modern bir } \\
\text { görünüşe sahip olması }\end{array}$ & 4,1909 & 0,8948 & 4,3561 & 0,8693 & $-0,1652$ \\
\hline $\begin{array}{l}\text { Kitap, dergi gibi yayınların en son } \\
\text { baskısına sahip olması }\end{array}$ & 3,6250 & 1,1304 & 4,3199 & 0,9335 & $-0,6949$ \\
\hline $\begin{array}{l}\text { CD, CD-ROM, DVD, ses kaseti vb. } \\
\text { kitap dışı materyalin yer aldığı bölüme } \\
\text { sahip olması }\end{array}$ & 3,6963 & 1,1318 & 4,2890 & 0,9362 & $-0,5927$ \\
\hline $\begin{array}{l}\text { Kütüphane internet sayfasının } \\
\text { kullanımının kolay olması }\end{array}$ & 3,8120 & 1,1334 & 4,3778 & 0,8975 & $-0,5658$ \\
\hline $\begin{array}{l}\text { Kütüphane veri tabanlarının yeterli } \\
\text { olması }\end{array}$ & 3,8514 & 1,0466 & 4,4318 & 0,8479 & $-0,5804$ \\
\hline $\begin{array}{l}\text { Katalog tarama sisteminin açık ve kolay } \\
\text { anlaşılır bilgilere sahip olması }\end{array}$ & 3,8608 & 1,0651 & 4,4091 & 0,8821 & $-0,5483$ \\
\hline TOPLAM & 3,9513 & 1,0101 & 4,3844 & 0,8649 & $-0,4331$ \\
\hline \multicolumn{6}{|l|}{ GÜVENİIIRLİK } \\
\hline $\begin{array}{l}\text { Kütüphane bir işi ne zaman yapacağını } \\
\text { taahhüt ediyorsa, bu işi o zamanda } \\
\text { gerçekleştirmesi }\end{array}$ & 3,9430 & 0,8927 & 4,3920 & 0,8163 & $-0,4490$ \\
\hline $\begin{array}{l}\text { Kütüphane çalışanlarının öğrencilerin } \\
\text { bir problemi olduğunda, bunu çözmek } \\
\text { için samimi bir ilgi göstermesi }\end{array}$ & 3,8661 & 1,0457 & 4,3571 & 0,8834 & $-0,4910$ \\
\hline $\begin{array}{l}\text { Öğrencilere yapılan işlemlerin ilk } \\
\text { seferde ve doğru olarak yapılması }\end{array}$ & 4,0345 & 0,8912 & 4,3897 & 0,8356 & $-0,3552$ \\
\hline $\begin{array}{l}\text { Kütüphane hizmetlerini söz verdiği } \\
\text { zamanda gerçekleştirmesi }\end{array}$ & 3,7670 & 1,0028 & 4,4086 & 0,8706 & $-0,6416$ \\
\hline $\begin{array}{l}\text { Öğrencilere ait kayıtların düzenli ve } \\
\text { eksiksiz olarak tutulması }\end{array}$ & 3,9457 & 0,9116 & 4,4052 & 0,8279 & $-0,4595$ \\
\hline TOPLAM & 3,9113 & 0,9488 & 4,3905 & 0,8468 & $-0,4792$ \\
\hline \multicolumn{6}{|l|}{ HEVESLİLIK } \\
\hline $\begin{array}{l}\text { Öğrencilere hizmetin tam olarak ne } \\
\text { zaman gerçekleştirileceğinin } \\
\text { söylenmesi }\end{array}$ & 3,8530 & 1,0334 & 4,3419 & 0,8766 & $-0,4889$ \\
\hline $\begin{array}{l}\text { Kütüphane çalışanlarının hizmetleri } \\
\text { mümkün olan en kisa sürede vermesi }\end{array}$ & 3,8917 & 0,9998 & 4,3097 & 0,9233 & $-0,4180$ \\
\hline $\begin{array}{l}\text { Kütüphane çalışanlarının her zaman } \\
\text { öğrenciye yardım etmeye istekli olması }\end{array}$ & 3,8750 & 1,0246 & 4,3343 & 0,8656 & $-0,4593$ \\
\hline
\end{tabular}


Tablo 3. Algılanan ve Beklenen Hizmet Kalitesi Değerlerinin Ortalama, Standart Sapma ve SERVQUAL Skorları (Devamı)

\begin{tabular}{|c|c|c|c|c|c|}
\hline \multirow{2}{*}{ HİZMET KALİTESİ İFADELERİ } & \multicolumn{2}{|c|}{$\begin{array}{l}\text { Algılanan Değerler } \\
\qquad(\alpha=0,946)\end{array}$} & \multicolumn{2}{|c|}{$\begin{array}{l}\text { Beklenen Değerler } \\
\qquad(\alpha=0,959)\end{array}$} & \multirow{2}{*}{$\begin{array}{l}\text { SERVQUAL } \\
\text { SKORU }\end{array}$} \\
\hline & $\begin{array}{c}\text { Aritmetik } \\
\text { Ortalama }\end{array}$ & $\begin{array}{l}\text { Standart } \\
\text { Sapma }\end{array}$ & $\begin{array}{l}\text { Aritmetik } \\
\text { Ortalama }\end{array}$ & $\begin{array}{l}\text { Standart } \\
\text { Sapma }\end{array}$ & \\
\hline \multicolumn{6}{|l|}{ HEVESLİLIKK } \\
\hline $\begin{array}{l}\text { Kütüphane çalışanlarının meşgul } \\
\text { olsalar dahi öğrencilerin isteklerine } \\
\text { cevap verebilmesi }\end{array}$ & 3,7074 & 1,0525 & 4,1841 & 08935 & $-0,4767$ \\
\hline TOPLAM & 3,8318 & 1,0276 & 4,2925 & 0,8898 & $-0,4607$ \\
\hline \multicolumn{6}{|l|}{ GÜVEN } \\
\hline $\begin{array}{l}\text { Kütüphane çalışanlarının } \\
\text { davranışlarıyla öğrencilere güven } \\
\text { vermesi }\end{array}$ & 4,0256 & 0,9208 & 4,4543 & 0,7883 & $-0,4287$ \\
\hline $\begin{array}{l}\text { Öğrencilerin kütüphane çalışanları ile } \\
\text { olan ilişkilerinde kendini güvende } \\
\text { hissetmesi }\end{array}$ & 3,9318 & 0,9905 & 4,3857 & 0,8843 & $-0,4539$ \\
\hline $\begin{array}{l}\text { Kütüphane çalışanlarının öğrencilere } \\
\text { karşı kibar olması }\end{array}$ & 3,9855 & 0,9719 & 4,4167 & 0,8292 & $-0,4312$ \\
\hline $\begin{array}{l}\text { Kütüphane çalışanlarının öğrencilerin } \\
\text { sorularına cevap verebilecek yeterli } \\
\text { bilgi seviyesine sahip olması }\end{array}$ & 3,8661 & 0,9632 & 4,3949 & 0,8305 & $-0,5288$ \\
\hline TOPLAM & 3,9523 & 0,9616 & 4,4129 & 0,8331 & $-0,4606$ \\
\hline \multicolumn{6}{|l|}{ EMPATİ } \\
\hline $\begin{array}{l}\text { Kütüphanede, ihtiyaçları } \\
\text { doğrultusunda öğrencilere bireysel ilgi } \\
\text { gösterilmesi }\end{array}$ & 3,8006 & 1,0637 & 4,2386 & 0,9151 & $-0,4380$ \\
\hline $\begin{array}{l}\text { Kütüphane çalışanlarının öğrencilere } \\
\text { kendini özel hissettirmesi }\end{array}$ & 3,6686 & 1,0743 & 4,1676 & 1,0087 & $-0,4990$ \\
\hline $\begin{array}{l}\text { Kütüphane çalışanlarının öğrencilerin } \\
\text { menfaatlerini her şeyin üstünde } \\
\text { tutması }\end{array}$ & 3,7642 & 1,0668 & 4,1753 & 0,9697 & $-0,4111$ \\
\hline $\begin{array}{l}\text { Kütüphanenin öğrenciler için elinden } \\
\text { gelenin en iyisini yapması }\end{array}$ & 3,8499 & 1,0071 & 4,4074 & 0,8224 & $-0,5575$ \\
\hline $\begin{array}{l}\text { Kütüphane çalışma saatlerinin } \\
\text { öğrenciler için uygun zaman diliminde } \\
\text { olması }\end{array}$ & 4,0684 & 0,9356 & 4,3739 & 0,8703 & $-0,3055$ \\
\hline TOPLAM & 3,8303 & 1,0295 & 4,2723 & 0,9173 & $-0,4420$ \\
\hline
\end{tabular}

Güvenilirlik boyutunda algılanan hizmet kalitesi ifadelerinden, öğrencilere yapılan işlemlerin ilk seferde ve doğru olarak yapılması $(4,0345)$ ve öğrencilere ait kayıtların düzenli ve eksiksiz olarak tutulması $(3,9457)$ değişkenleri öne çıkmaktadır. Beklenen hizmet kalitesi açısından ise kütüphane hizmetleri söz verdiği zaman gerçekleştirmesi $(4,4086)$ ve öğrencilere ait kayıtların eksiksiz ve düzenli olarak tutulması önemli olan değişkenlerdir. Kütüphane hizmetlerinin güvenilirlik açısından kalitesinin tespitinde kullanılan Servqual skoru -0,4792 olarak hesaplanmıştır. Bu sonuçla, kütüphane çalışanlarının öğrencilerde kütüphane hizmetlerinde karşı güvenilirliğin oluşmasında yeterli olmadığı düşünülebilir.

Yukarıdaki tablodan görüldügü üzere heveslilik boyutu incelendiğinde, kütüphane çalışanlarının hizmetleri mümkün olan en kısa sürede vermesi $(3,8917)$ ve kütüphane çalışanlarının her zaman öğrenciye yardım etmeye istekli olması $(3,8750)$ algılanan hizmet kalitesinde öne çıkan ifadeleri oluşturmaktadır. Beklenen hizmet kalitesinde ise kütüphane 
çalışanlarının hizmetleri mümkün olan en kısa sürede vermesi $(4,3419)$ ve kütüphane çalışanlarının her zaman öğrenciye yardım etmeye istekli olması $(4,3343)$ öne çıkmaktadır. Kütüphane çalışanlarının heveslilikleri için algı ve beklenti ortalamaları ile hesaplanan Servqual skoru -0,4607 olarak hesaplanmıştır. Bu skorla, kütüphane çalışanlarının hizmet sunumunu hevesle yapmadıkları söylenebilir.

Algılanan hizmet kalitesinin güven boyutu incelendiğinde, kütüphane çalışanlarının davranışlarıyla öğrencilere güven vermesi $(4,0256)$ ve kütüphane çalışanlarının öğrencilere karşı kibar olması $(3,9855)$ ifadeleri öne çıkmaktadır. Beklenen hizmet kalitesinde ise kütüphane çalışanlarının davranışlarıyla öğrencilere güven vermesi $(4,4543)$ ve kütüphane çalışanlarının öğrencilere karşı kibar olması $(4,4167)$ öne çıkan ifadeleri oluşturmaktadır. Kütüphaneye duyulan güven için algı ve beklenti ortalamaları ile hesaplanan Servqual skoru $-0,4606$ olarak hesaplanmıştır. Bu sonuçtan katılımcıların kütüphane hizmetlerine karşı güven duymadıkları ifade edilebilir.

Empati boyutunda algılanan hizmet kalitesi ifadelerinden, kütüphane çalışma saatlerinin öğrenciler için uygun zaman diliminde olması $(4,0684)$ ve kütüphanenin öğrenciler için elinden gelenin en iyisini yapması $(3,8499)$ değişkenleri öne çıkmaktadır. Beklenen hizmet kalitesi açısından ise kütüphanenin öğrenciler için elinden gelenin en iyisini yapması $(4,4074)$ ve kütüphane çalışma saatlerinin öğrenciler için uygun zaman diliminde olması $(4,3739)$ önemli olan değişkenlerdir. Hizmet kalitesinin empati boyutunun Servqual skoru -0,4420 olarak hesaplanmıştır. Bu sonuçla, cevaplayıcıların kütüphane hizmetlerinde çalışanların kendini öğrencinin yerine koyamadıkları düşünülebilir.

\subsubsection{Beklenen ve Algılanan Hizmet Kalitesi Boyutları ile Demografik, Ekonomik ve Kütüphane Kullanma Özellikleri Arasındaki İlişkiler}

Cevaplayıcıların beklenen ve algilanan hizmet kalitesi boyutları ile demografik, ekonomik ve kütüphane kullanma özellikleri arasındaki ilişki incelenmiştir. Cevaplayıcıların bu ilişkileri Tablo 4'de gösterilmiştir. Beklenen ve algılanan hizmet kalitesi boyutlarını sırasıyla ele alıp demografik, ekonomik ve kütüphane kullanma özelliklerle ilişkisine bakıldığında aşağıdaki sonuçlar elde edilmiştir. Beklenen fiziksel özellikler ile demografik, ekonomik ve kütüphane kullanma özellikleri arasındaki ilişkiye bakıldığında cinsiyet $(-0,108$, $p<0,05)$, yaş $(-0,189, p<0,01)$, eğitim gördüğü sınıf $(-0,135, p<0,05)$ ve kütüphane kullanma amacı $(-0,135, p<0,05)$ ile negatif yönde anlamlı ilişki olduğu görülmüştür. Buna göre k1z öğrencilerin, yaşı gençlerin, birinci sınıfların ve kütüphaneyi ders çalışmak amacıyla kullanan öğrencilerin kütüphanenin fiziksel özelliklerine önem vermektedirler.

Beklenen güvenilirlik ile demografik, ekonomik ve kütüphane kullanma özellikleri arasındaki ilişkiye bakıldığında cinsiyet $(-0,137, p<0,05)$, yaş $(-0,189, p<0,01)$ ve eğitim gördüğü sinıf $(-0,130, p<0,05)$ ile negatif yönde anlamlı ilişki olduğu görülmüştür. Bu boyuta önem verenlerin kız, genç ve birinci sınıfta eğitim gören öğrencilerdir. Beklenen heveslilik ile demografik, ekonomik ve kütüphane kullanma özellikleri arasındaki ilişkiye bakıldığında cinsiyet $(-0,121, p<0,05)$, yaş $(-0,166, p<0,01)$, gelir $(-0,125, p<0,05)$, eğitim gördüğü sinıf ($0,135, p<0,05)$ ve kütüphane kullanma amacı $(-0,135, p<0,05)$ ile negatif yönde anlamlı ilişki olduğu görülmüştür. Bu boyuta önem verenlerin kız, genç, öğrenci harçlıklarının düşük, birinci sınıfta eğitim gören ve kütüphaneyi ders çalışmak için kullanan öğrenciler olduğu görülmektedir. 
Beklenen güven ile demografik, ekonomik ve kütüphane kullanma özellikleri arasındaki ilişkiye bakıldığında cinsiyet $(-0,157, p<0,01)$, yaş $(-0,112, p<0,05)$, eğitim gördüğü sinıf $(-0,127, p<0,05)$ ve kütüphane kullanma amacı $(-0,122, p<0,05)$ ile negatif yönde anlamlı ilişki olduğu görülmüştür. Bu boyuta önem verenlerin kız, genç, birinci sınıfta eğitim gören ve kütüphaneyi ders çalışmak için kullanan öğrenciler olduğu görülmektedir. Beklenen empati ile demografik, ekonomik ve kütüphane kullanma özellikleri arasındaki ilişkiye bakıldığında cinsiyet $(-0,127, p<0,05)$, yaş $(-0,181, p<0,01)$, eğitim gördüğ̈̈ sınıf $(-0,162$, $p<0,01)$ ve kütüphane kullanma amacı $(-0,129, p<0,05)$ ile negatif yönde anlamlı ilişki olduğu görülmüştür. Bu boyuta önem verenlerin $\mathrm{klz}$, genç, birinci sinıfta eğitim gören ve kütüphaneyi ders çalışmak için kullanan öğrencilerdir.

Tablo 4. Beklenen ve Algılanan Hizmet Kalitesi Boyutları ile Demografik, Ekonomik ve Kütüphane Kullanma Özellikleri Arasındaki İlişkiler

\begin{tabular}{|c|c|c|c|c|c|c|c|c|}
\hline \multicolumn{2}{|c|}{$\begin{array}{c}\text { Demografik ve } \\
\text { Ekonomik Özellikler } \\
\text { Algılanan ve } \\
\text { Beklenen Değerler }\end{array}$} & \multirow{2}{*}{$\begin{array}{l}\text { Cinsiyet } \\
-, 108^{*}\end{array}$} & \multirow{2}{*}{$\begin{array}{l}\text { Yaş } \\
-, 189^{* *}\end{array}$} & \multirow{2}{*}{$\begin{array}{l}\text { Gelir } \\
-, 056\end{array}$} & \multirow[t]{2}{*}{$\begin{array}{l}\begin{array}{l}\text { Ĕ̆itim } \\
\text { Gördüğü } \\
\text { Okul }\end{array} \\
, 061\end{array}$} & \multirow{2}{*}{$\begin{array}{l}\begin{array}{l}\text { Eğitim } \\
\text { Gördüğ̈ü } \\
\text { Sinıf }\end{array} \\
-, 135^{*}\end{array}$} & \multirow[t]{2}{*}{$\begin{array}{l}\begin{array}{l}\text { Kütüphane } \\
\text { Kullanma } \\
\text { Sıklığ1 }\end{array} \\
-, 093\end{array}$} & \multirow[t]{2}{*}{$\begin{array}{l}\begin{array}{l}\text { Kütüphane } \\
\text { Kullanma } \\
\text { Amac1 }\end{array} \\
-, 135^{*}\end{array}$} \\
\hline Beklenen & Kor.K. & & & & & & & \\
\hline Fiziksel & p. & ,048 & ,001 & ,307 & 268 & ,013 & ,092 & ,015 \\
\hline Özellikler & $\mathrm{n}$ & 378 & 378 & 378 & 378 & 378 & 378 & 378 \\
\hline \multirow{3}{*}{$\begin{array}{l}\text { Beklenen } \\
\text { Güvenilirlik }\end{array}$} & Kor.K. &,$- 137^{*}$ &,$- 154^{* *}$ &,- 060 &,- 021 &,$- 130^{*}$ &,- 044 &,- 084 \\
\hline & p. & ,012 & ,005 & 276 & 706 & ,017 & ,054 & 127 \\
\hline & $\mathrm{n}$ & 378 & 378 & 378 & 378 & 378 & 378 & 378 \\
\hline \multirow{3}{*}{$\begin{array}{l}\text { Beklenen } \\
\text { Heveslilik }\end{array}$} & Kor.K. &,$- 121^{*}$ &,$- 166^{* *}$ &,$- 125^{*}$ & , 045 &,$- 135^{*}$ &,- 093 &,$- 135^{*}$ \\
\hline & p. & ,025 & ,002 & ,021 & ,404 & ,012 & ,087 & ,014 \\
\hline & $\mathrm{n}$ & 378 & 378 & 378 & 378 & 378 & 378 & 378 \\
\hline \multirow{3}{*}{$\begin{array}{l}\text { Beklenen } \\
\text { Güven }\end{array}$} & Kor.K. &,$- 157^{* *}$ &,$- 112^{*}$ &,- 087 & ,006 &,$- 127^{*}$ &,- 019 &,$- 122^{*}$ \\
\hline & p. & ,004 & ,042 & 115 & ,910 & ,021 & ,736 & ,028 \\
\hline & $\mathrm{n}$ & 378 & 378 & 378 & 378 & 378 & 378 & 378 \\
\hline \multirow{3}{*}{$\begin{array}{l}\text { Beklenen } \\
\text { Empati }\end{array}$} & Kor.K. &,$- 127^{*}$ &,$- 181^{* *}$ &,- 028 & , 052 &,$- 162^{* *}$ &,- 037 &,$- 129^{*}$ \\
\hline & p. & ,019 & ,001 & 601 & ,339 & ,003 & ,493 & ,019 \\
\hline & $\mathrm{n}$ & 378 & 378 & 378 & 378 & 378 & 378 & 378 \\
\hline \multirow{3}{*}{$\begin{array}{l}\text { Algılanan } \\
\text { Fiziksel } \\
\text { Özellikler }\end{array}$} & Kor.K. &,- 176 &,- 103 &,- 005 &, $185^{* *}$ &,- 080 &,$- 134^{*}$ &,$- 128^{*}$ \\
\hline & p. & 164 & ,060 & ,931 & ,001 & 144 & ,015 & ,022 \\
\hline & $\mathrm{n}$ & 378 & 378 & 378 & 378 & 378 & 378 & 378 \\
\hline \multirow{3}{*}{$\begin{array}{l}\text { Algılanan } \\
\text { Güvenilirlik }\end{array}$} & Kor.K. & -088 &,$- 158^{* *}$ &,- 028 & $164^{* *}$ &,$- 148^{* *}$ &,$- 193^{* *}$ &,- 072 \\
\hline & p. & 106 & ,003 & 602 & ,002 & ,006 & ,000 & 189 \\
\hline & $\mathrm{n}$ & 378 & 378 & 378 & 378 & 378 & 378 & 378 \\
\hline \multirow{3}{*}{$\begin{array}{l}\text { Algilanan } \\
\text { Heveslilik }\end{array}$} & Kor.K. & -,203 &,$- 139^{* *}$ & -021 & $234^{* *}$ &,- 075 &,$- 128^{*}$ &,- 064 \\
\hline & p. & 671 & 010 & 703 & ,000 & 165 & 018 & 243 \\
\hline & $\mathrm{n}$ & 378 & 378 & 378 & 378 & 378 & 378 & 378 \\
\hline \multirow{3}{*}{$\begin{array}{l}\text { Algılanan } \\
\text { Güven }\end{array}$} & Kor.K. & ,003 &,$- 112^{*}$ & ,050 & $165^{* *}$ & $-137^{*}$ &,$- 140^{* *}$ &,- 072 \\
\hline & p. & ,950 & ,038 & ,358 & ,002 & ,011 & ,010 & 191 \\
\hline & $\mathrm{n}$ & 378 & 378 & 378 & 378 & 378 & 378 & 378 \\
\hline \multirow{3}{*}{$\begin{array}{l}\text { Algilanan } \\
\text { Empati }\end{array}$} & Kor.K. &,- 003 &,$- 114^{*}$ &,- 018 & $206^{* *}$ &,- 086 &,$- 109^{*}$ &,$- 125^{*}$ \\
\hline & p. & 959 & ,034 & 738 & ,000 & 109 & ,044 & ,021 \\
\hline & & 378 & 378 & 378 & 378 & 378 & 378 & 378 \\
\hline
\end{tabular}

${ }^{* *} p<0,01-{ }^{*} p<0,05$

Algilanan fiziksel özellikler ile demografik, ekonomik ve kütüphane kullanma özellikleri arasındaki ilişkiye bakıldığında eğitim gördüğü okul $(-0,185, p<0,01)$, kütüphane kullanma sıklığı $(-0,134, p<0,05)$ ve kütüphane kullanma amac1 $(-0,12, p<0,05)$ ile negatif yönde anlamlı ilişki olduğu görülmüştür. $\mathrm{Bu}$ boyuta önem verenlerin enstitülerde ve 
fakültelerde eğitim gören, kütüphaneyi her gün kullanan öğrenciler olduğu görülmektedir. Alg1lanan güvenilirlik ile demografik, ekonomik ve kütüphane kullanma özellikleri arasındaki ilişkiye bakıldığında yaş $(-0,158, p<0,01)$, eğitim gördüğü okul $(-0,164, p<0,01)$, eğitim gördüğü sınıf $(-0,148, p<0,01)$ ve kütüphane kullanma sıklığ1 $(-0,193, p<0,01)$ ile negatif yönde anlamlı ilişki olduğu görülmüştür. Bu boyuta önem verenler, birinci sinıfta eğitim gören, fakültelerde eğitime devam eden ve kütüphaneyi her gün kullanan öğrencilerdir.

Algılanan heveslilik ile demografik, ekonomik ve kütüphane kullanma özellikleri arasındaki ilişkiye bakıldığında yaş $(-0,139, \mathrm{p}<0,01)$, eğitim gördüğü okul $(-0,234, p<0,01)$ ve kütüphane kullanma amacı $(-0,128, p<0,05)$ ile negatif yönde anlamlı ilişki olduğu görülmüştür. Bu boyuta önem verenlerin genç, fakültelerde eğitim gören ve kütüphaneyi ders çalışmak için kullanan öğrencilerdir. Algılanan güven ile demografik, ekonomik ve kütüphane kullanma özellikleri arasındaki ilişkiye bakıldığında yaş $(-0,112, p<0,05)$, eğitim gördüğü okul $(-0,165, p<0,01)$, eğitim gördüğü sinıf $(-0,137, p<0,05)$ ve kütüphane kullanma amacı $(-0,140, p<0,01)$ ile negatif yönde anlamlı ilişki olduğu görülmüştür. Bu boyuta önem verenleri fakültelerde eğitim gören, genç, birinci sınıf, kütüphaneyi her gün kullanan ve kütüphaneyi ders çalışmak için kullanan öğrenciler oluşturmaktadır. Algılanan empati ile demografik, ekonomik ve kütüphane kullanma özellikleri arasındaki ilişkiye bakıldığında yaş $(-0,114, p<0,05)$, eğitim gördüğü okul $(-0,206, p<0,01)$, kullanma sıklı̆̆ $(-0,109, p<0,05)$ ve kütüphane kullanma amacı $(-0,125, p<0,05)$ ile negatif yönde anlamlı ilişki olduğu görülmüştür. Bu boyuta önem verenlerin genç, fakültelerde eğitim gören, her gün kütüphaneyi kullanan ve kütüphaneyi ders çalışmak için kullanan öğrencilerdir.

\subsubsection{Beklenen ve Algilanan Hizmet Kalitesi Arasında Fark}

Cevaplayıcıların bekledikleri hizmet kalitesi ile algıladıkları hizmet kalitesi arasında farklılık olup olmadığını görmek için $t$ testi yapılmış ve çıkan sonuçlar Tablo 5'de sunulmuştur.

Tablo 5. Beklenen ve Algılanan Hizmet Kalitesi Arasındaki t-testi Değerleri

\begin{tabular}{|c|c|c|c|c|c|c|c|c|}
\hline & \multicolumn{8}{|c|}{ Eşleştirilmiş Farklar } \\
\hline & \multirow{2}{*}{ Ortalama } & \multirow{2}{*}{$\begin{array}{c}\text { Standart } \\
\text { Sapma }\end{array}$} & \multirow{2}{*}{$\begin{array}{l}\text { Standart } \\
\text { Hata }\end{array}$} & \multicolumn{2}{|c|}{$\begin{array}{l}\text { \%95 Güven } \\
\text { Aralığı Farkı }\end{array}$} & \multirow{2}{*}{$\begin{array}{c}t \\
\text { değeri }\end{array}$} & \multirow{2}{*}{$\begin{array}{c}\text { Serbestlik } \\
\text { Derecesi }\end{array}$} & \multirow[b]{2}{*}{$\mathrm{p}$} \\
\hline & & & & $\begin{array}{c}\text { En } \\
\text { Düssük }\end{array}$ & $\begin{array}{c}\text { En } \\
\text { Yüksek }\end{array}$ & & & \\
\hline $\begin{array}{l}\text { Beklenen Fiziksel } \\
\text { Özellikle-Algilanan } \\
\text { Fiziksel Özellikler }\end{array}$ & 0,43576 & 0,65796 & 0,03701 & 0,36294 & 0,50858 & 11,773 & 315 & 0,000 \\
\hline $\begin{array}{l}\text { Beklenen } \\
\text { Güvenilirlik- } \\
\text { Algilanan } \\
\text { Güvenilirlik }\end{array}$ & 0,46111 & 0,74108 & 0,04117 & 0,38011 & 0,54211 & 11,200 & 323 & 0,000 \\
\hline $\begin{array}{l}\text { Beklenen } \\
\text { Heveslilik- } \\
\text { Algilanan } \\
\text { Heveslilik }\end{array}$ & 0,44925 & 0,83076 & 0,04539 & 0,35997 & 0,53854 & 9,898 & 334 & 0,000 \\
\hline $\begin{array}{l}\text { Beklenen Güven- } \\
\text { Algılanan Güven }\end{array}$ & 0,46661 & 0,79514 & 0,04431 & 0,37944 & 0,55379 & 10,530 & 321 & 0,000 \\
\hline $\begin{array}{l}\text { Beklenen Empati- } \\
\text { Algllanan Empati }\end{array}$ & 0,44235 & 0,80842 & 0,04384 & 0,35612 & 0,52859 & 10,090 & 339 & 0,000 \\
\hline
\end{tabular}


Yukarıdaki tabloda görüldüğ̈̈ gibi, beklenen ve algılanan kalite boyutları (fiziksel özellikler, güvenilirlik, heveslilik, güven ve empati) arasında anlamlı farklılık olduğu görülmektedir. Bu sonuçlara göre $\mathrm{H} 1$ “Uşak Üniversitesi Kütüphanesinin sahip olduğu fiziksel özellik açısından beklenen hizmet kalitesi ile algılanan hizmet kalitesi arasında farklılık vardır", H2 "Uşak Üniversitesi Kütüphanesine duyulan güvenilirlik açısından beklenen hizmet kalitesi ile algılanan hizmet kalitesi arasında farklılık vardır", H3 "Uşak Üniversitesi Kütüphanesi çalışanlarının hevesliliği açısından beklenen hizmet kalitesi ile algılanan hizmet kalitesi arasında farklılık vardır", H4 "Uşak Üniversitesi Kütüphanesine duyulan güven bakımından beklenen hizmet kalitesi ile algilanan hizmet kalitesi arasında farklılık vardır" ve H5 "Uşak Üniversitesi Kütüphanesi çalışanlarının kurduğu empati açısından beklenen hizmet kalitesi ile algılanan hizmet kalitesi arasında farklılık vardır" hipotezleri kabul edilmiştir.

\section{SONUÇ VE ÖNERILER}

Uşak Üniversitesi Merkez Kütüphanesi'nin sunduğu hizmet kalitesinin kullanıcı beklentilerini karşılama derecesi belirlemek amacını taşıyan bu çalışmada şu sonuçlar elde edilmiştir:

Araştırmaya katılan cevaplayıcılar, çoğunlukla kız, 301-600 TL arası gelire sahip, birinci sınıf ve fakültelerde eğitim görülmüş̧tür. Kütüphane kullanım amaçlarının başında ders çalışmak ve araştırma yapmak gelmekte ve bu amaçlar doğrultusunda haftada en az 2 gün kütüphane kullanılmaktadır.

Cevaplayıcılar, kütüphanenin modern bir görünüşe sahip olduğunu ve mobilya, dekorasyon, aydınlatma gibi görsel açıdan çekici olduğunu belirtmektedir. Ancak, algılamaları bu yönde olan cevaplayıcılar, kütüphanenin modern araç ve gerece sahip olması ile çalışanların düzgün ve temiz olması konusunda ise beklentilerinin yüksek olduğu görülmektedir. CD, DVD gibi sesli kütüphane hizmetleri ve internet sayfası cevaplayıcıların beklentilerini yeterli şekilde karşılamaktadır. Basılı eserler bakımından öğrenciler daha fazla kaynak beklentisine sahiptirler. Sonuç olarak kütüphane fiziksel görünüm açısından öğrencilerin beklentilerini karşılamada yetersiz kalmaktadır.

Öğrenciler çalışanların hizmet vermeye isteklilikleri ve hizmetleri mümkün olan en kısa sürede vermeleri algıları ile beklentileri arasındaki farkın düşük olması çalışanların hizmet sunumu esnasında hevesli oldukları söylenebilir. Ayrıca öğrencilerin çalışanlar ile olan ilişkilerinde ise güvende hissetmemelerine yol açmaktadır. Güven boyutunun diğer bir ifadesi olan çalışanların kibarlık algılaması ile beklenti arasındaki farkın düşük olması personelin kibar olduğu göstermektedir.

Beklenen hizmet kalitesi ile algılanan hizmet kalitesi ortalamalarının anlamlı bir farklılık bulunmuş olup, beklenen hizmet kalitesinin algılanan genel hizmet kalitesinden yüksek olduğu görülmektedir. Bu durum, kütüphanenin öğrenciler için genel memnuniyet düzeyinin tam olarak sağlanamadığı kanaati oluşturmaktadır.

Bu sonuçlar doğrultusunda şu önerilerde bulunulabilir;

- Kütüphanede bulunan kantin, tuvalet gibi ortak kullanım alanlarının temizliği ve düzeni iyi seviyede ancak yeterli bulmamaktadır. Bu tesislerin temizliği konusunda biraz daha fazla hassas olunmalıdır. 
- Kütüphane binası modern görünüşe sahip, mobilya, dekor, aydınlatma gibi hususlarda iyi seviyededir. Ancak bunların korunmasına ve bakımına daha fazla dikkat edilmelidir.

- Öğrencilerin çoğu kütüphaneyi ders çalışmak ve araştırma yapmak amacıyla kullanmakta ve mevcut kaynaklardan daha verimli bir şekilde yararlanabilmek için zamanlarının çoğunu kütüphane binasında harcamaktadır. Bu bağlamda ders çalışma alanlarının geliştirilmesi ve arttırılması faydalı olacaktır.

- Kütüphanedeki basılı ve süreli yayınların son baskı ve sayısının arttırılması araştırma amacıyla kütüphaneden yararlanmayı artırabilir.

- Sesli kütüphanenin etkin olarak oluşturulması, internet sayfasının ve katalog tarama programının basitleştirilmesi ile verin tabanlarının ihtiyacı karşılayacak şekilde abone olunması öğrencilerin Uşak Üniversitesi hakkındaki oluşabilecek olumsuz düşüncelerin oluşmasına ve yayılmasına engel olacaktır.

- Kütüphane çalışanları yapacakları işlerde mutlaka söz verdikleri zamanda işlemleri gerçekleştirmeli, öğrencilerin kütüphane kaynaklı karşılaştıkları sorunları çözmek için istekli olması, teknolojinin geliştiği ve kullanıcı kayıtların tutulduğu otomasyon sisteminin yedeklenerek herhangi bir aksaklığa yol açılmaması ve hizmetlerin ilk seferde ve doğru olarak yapılması çalışanlara duyulan güvenirliğin oluşmasını arttırabilir.

- Kütüphane çalışma saatlerinin öğrencilerin faydalı şekilde yararlanması için uygun zaman dilimlerinde olması ve çalışma odalarının edebiyat, tarih, işletme gibi ihtisas odaları şeklinde düzenlenmesi ve ilgili kaynakların bu odalarda yer alması araştırma için gereken zamanın kısalması için uygun olabilir.

- Kütüphane içerisinde fotokopi, CD çoğaltma gibi çeşitli hizmetler gereği gibi yerine getirilmeli ve yeterli sayıda olmalıdır. Ayrıca kütüphane yönetiminin sadece mevcut olan bilgi kaynakları ve ona ulaşmayı sağlayacak teknolojik altyapı geliştirilmesi yeterli değil aynı zamanda kullanıcıya da önem vermelidir. Bu önemi verebilmek bir diğer ifadeyle kaliteyi iyileştirebilmek için de sık sık hizmet kalitesi ölçümü araştırmaları ve çalışmaları yapılmalıdır.

- Literatür incelemesinde belirtilen Herbert (1994) çalışmasında Servqual ölçeğini kullanmış ancak yeterli olmadığını gördüğü için bazı ilave ifadeler eklemiştir. Bu çalışmada da özellikle fiziksel özelliklerin kütüphane hizmet kalitesini ölçmede yeterli olmadığ1 görülmüş ve yeni ifadeler eklenmiştir.

- Cook ve Thompson (2000) çalışmasında ise hizmet ölçümünün zamana ve uygulanan gruplara göre farklılık göstereceğini belirtmişlerdir. Bu çalışmanın sonucunda ise özellikle yüksek öğretime yeni başlayanları kütüphaneyi aktif olarak kullandığı görülmüştür. Eğer farklı sınıflarda eğitim gören öğrencilerin kütüphane hizmet kalitesinin ölçülmesinin yararlı olacağı düşünülmektedir.

- Gelecek yapılacak çalışmalarda Servqual ölçeğine bu çalışmada eklenen fiziksel özellik ifadelerinin ilave edilmesi ve çalışmada akademik hayat süresinin kütüphane hizmet algısındaki farklılığa bakılmasının uygun olacağı önerilmektedir.

- Gelecek çalışmalarda elektronik kütüphane hizmet kalitesinin ölçülmesinin de yararlı olacağı düşünülmektedir. 


\section{KAYNAKÇA}

Atan, M., Baş, M. ve Tolon, M. (2010). Servqual Analizi ile Süpermarketlerde Hizmet Kalitesinin Ölçülmesine Yönelik Bir Alan Çalışması. Gazi Üniversitesi İ.I..B.F Dergisi, 12(2):1-16.

Aydın, Ş. (2007). Hizmet Kalitesi Kavramlar, Yaklaşımlar ve Uygulamalar, (Ed. Akbaba, A., Tavmergen, İ.G., Akan, P., Gümüşoğlu, Ş.,) Detay Yayıncılık, Ankara.

Brown, T.J., Churchill, G.A. ve Peter, J.P. (1993). Improving the Measurement of Service Quality. Journal of Retailing, 69(1):127-139.

Cook, T. ve Thompson B. (2000). Reliability and Validity of SERVQUAL Scores Used to Evaluate Perceptions of Library Service Quality. The Journal of Academic Librarianship, 26:248-258.

Çelik, H. (2011). Alışveriş Merkezlerinde Hizmet Kalitesi Algısı ve Bir Araştırma. Süleyman Demirel Üniversitesi İktisadi ve İdari Bilimler Fakültesi Dergisi, 16(2):433-448.

Çiçek, R. ve Doğan, İ. (2009). Müşteri Memnuniyetinin Arttırılmasında Hizmet Kalitesinin Ölçülmesine Yönelik Bir Araştırma: Niğde İli Örneği. Afyon Kocatepe Üniversitesi İktisadi ve İdari Bilimler Fakültesi Dergisi, 11(1):199-217.

Doğan İ. Ö. ve Tütüncü, Ö. (2003). Hizmet İşletmelerinde Toplam Kalite Yönetimi Kapsamında ISO 9001:2000 ve Bilgisayar Destekli Bir Uygulama, Dokuz Eylül Üniversitesi Rektörlük Matbaası, İzmir.

Dursun, T., Oskaybaş, K. ve Gökmen, C. (2014). Hizmet Kalitesi ve Müşteri Memnuniyetinin Şubeİnternet Bankacıllı̆̆ında Karşılaştırılması. Marmara Üniversitesi Öneri Dergisi, 11(41):95-114.

Eleren, A. ve Kılıç, B. (2007). Turizm Sektöründe Servqual Analizi İle Hizmet Kalitesinin Ölçülmesi ve Bir Termal Otelde Uygulama. Afyon Kocatepe Üniversitesi, İ.I.B.F. Dergisi, 9(1):235-263.

Ersöz, S., Pınarbaşı, M., Kürşat Türker, A.K. ve Yüzükırmızı, M. (2009). Hizmet Kalitesinin Servqual Metodu ile Ölçümü ve Sonuçların Yapısal Eşitlik Modelleri ile Analizi: Öğretmen Evi Uygulamas1. International Journal of Engineering Research and Development, 1(1):19-27.

Filiz, Z., Yılmaz, E. ve Ceren Yağızer, C. (2010). Belediyelerde Hizmet Kalitesinin Servqual Analizi İle Ölçümü: Eskişehir Belediyelerinde Bir Uygulama. Anadolu Üniversitesi Sosyal Bilimler Dergisi, 10(3):59-76.

Grönroos, C. (1983). A Service Quality Model and Its Marketing Implications. European Journal of Marketting, 18(4):36-44.

Gürbüz, E. ve Ergülen, A. (2006). Hizmet Kalitesinin Ölçümü ve Grönroos Modeli Üzerine Bir Araştırma. İstanbul Üniversitesi Siyasal Bilgiler Fakültesi Dergisi, 35(Ekim Sayısı):173-190.

Güzel, D. ve Kotan, G. (2013). Kütüphanelerde Hizmet Kalitesi Ölçümü Atatürk Üniversitesi Merkezi Kütüphanesi'nde Bir Uygulama. Kahramanmaraş Sütçü İmam Üniversitesi İ̈BF Dergisi, 3(2):1124.

Heizer, J. ve Render, B. (2011). Operations Management, Pearson, Tenth Ed., New Jersey.

Hemedoğlu, E. (2012). Metro Hizmetlerinde Hizmet Kalitesini Ölçme: Algılanan Hizmet Kalitesi ve Beklenen Hizmet Kalitesi Üzerine Bir Karşılaştırma. Yönetim Dergisi, 23(72):25-47.

Herbert, F. (1994). Service Quality: An Unobtrusive Investigation of Interlibrary Loan in Large Public Libraries in Canada. Library and Information Science Research, 16:3-21.

Hernon, P. ve Calvert, T.P. (2005). E-Service Quality in Libraries: Exploring its Features and Dimensions. Library \& Information Science Research, 27:377-404.

Hoyle, D. (2007). Quality Management Essentials, Butterworth-Heinemann, Jordan Hill. 
İslamoğlu, A. H. ve Alnıaçık, Ü. (2013). Sosyal Bilimlerde Araştırma Yöntemleri, Geliştirilmiş ve Gözden Geçirilmiş 3. Baskı, Beta Yayınevi, İstanbul.

İzci, F. ve Saydam, R. (2013). Algılanan Hizmet Kalitesi Kurumsal İmaj ve Sadakat İlişkisi (Van Bölge Hastanesi Uygulaması). C.Ü. İktisadi ve İdari Bilimler Dergisi, 14(1):199-219.

Kang G., (2006). The Hierarchical Structure of Service Quality: Integration of Technical and Functional Quality. Managing Service Quality, 16(1):37-50.

Karahan, Ş. ve Kayabaşı, A. (2013). Kütüphane Hizmetlerinde Kalite Ölçümü: Dumlupınar Üniversitesi Merkez Kütüphanesi Üzerine Bir Araştırma. Dumlupınar Üniversitesi Sosyal Bilimler Dergisi, 35:185-198.

Kavak, B., Soğanc1, E. ve Eryigit, C. (2013). Servqual İle ‘Beklenti'nin Ölçümüne Yönelik Bir Kritik. Pazarlama ve Pazarlama Araştırmaları Dergisi, 12:81-98.

Kayral, İ. H. (2014). Perceived Service Quality in Healthcare Organizations and a Research in Ankara by Hospital Type. Journal of Ankara Studies, 2(1):22-34.

Kotler, P. ve Armstrong, G. (2011). Principles of Marketing. Pearson Prentice Hall, International Edition, 14th Edition, New Jersey.

Kristensen, K. ve Eskildsen, J., (2012). The Relationship Between SERVQUAL, National Customer Satisfaction Indices, and Consumer Sentiment. Quality Management Journal, 19(2):47-61.

Ladhari, R. ve Morales, M. (2008). Perceived Service Quality, Perceived Value and Recommendation: A Study Among Canadian Public Users. Library Management, 29(4/5):352-366.

Lehtinen, U. ve Lehtinen, J.R. (1983). Service Quality: A Study of Quality Dimensions. Unpublished Working Paper, Helsinki: Service Management Institude.

Mbise, E. Ve Tuninga, R.S. (2013). The Application of SERVQUAL to Business Schools in an Emerging Market: The Case of Tanzania. Journal of Transnational Management, 18(2):101-124.

Moss, H. K. (2007). Improving Service Quality With The Theory Of Constraints. Journal of the Academy Of Business \& Economics, 7(3):3-15.

Naik, K. ve Srinivasan, S.R., (2015). An Assessment of Departmental Store Service Effectiveness Using a Modified SERVQUAL Approach. Journal of Business \& Retail Management Research, 9(2):27-43.

Negi, R. (2009). Determining Customer Satisfaction Through Perceived Service Quality: A Study of Ethiopian Mobile Users. International Journal of Mobile Marketing, 4(1):31-38.

Öztürk, A.S. (2013). Hizmet Pazarlamast: Kuram, Uygulama ve Örnekler. Genişletilmiş ve Güncellenmiş 13. Baskı, Ekin Basım Yayın Dağıtım, Bursa.

Parasuraman, A., Zeithaml, V., Zeithalm A. ve Berry, L. L. (1985). A Conceptual Model of Service Quality and Its Implications for Future Research. Journal of Marketing, 49:41-50.

Parasuraman, A., Zeithaml, V.A. and Berry, L.L. 1988. SERVQUAL: A Multiple-Item Scale for Measuring Consumer Perceptions of Service Quality. Journal of Retailing, 64(1):12-40.

Savaş, H. ve Kesmez, A.G. (2014). Hizmet Kalitesinin Servqual Modeli İle Ölçülmesi: Aile Sağlığı Merkezleri Üzerine Bir Araştırma. Pamukkale Üniversitesi Sosyal Bilimler Enstitüsü Dergisi, 17:113.

Taşkın, Ç., Akat, Ö. ve Erol, Z. (2010). Tüketicilerin Banka Tercihini Etkileyen Faktörlerin Belirlenmesi: Bursa'da Bir Araştırma. Anadolu Üniversitesi Sosyal Bilimler Dergisi, 10(3):11-22.

Untaru, E.N., Ispas, A. ve Dan, I. (2015). “Assessing the Quality of Banking Services using the SERVQUAL Model", Romanian Journal of Marketing, Issue:2, ss.84-92. 
Wang, I. ve Shieh C. (2006). The Relationship between Service Quality and Customer Satisfaction: The Example of CJCU Library. Journal of Information \& Optimization Sciences, 27(1):193-209.

Wang, Y., Luor, T., Luarn, P. ve Lu, H.,(2015). Contribution and Trend to Quality Research-a literature review of SERVQUAL model from 1998 to 2013. Informatica Economica, 19(1):34-45.

Yıldız, S.M. (2009). Katılıma Dayalı Spor Hizmetlerinde Hizmet Kalitesi Modelleri. Ege Akademik Bakı̧, 9(4):1213-1224.

Zakaria, Z., Hussin, Z.H., Noordin, N., Sawal, M.Z.M.H., Alhady, S.M.A.B.S.A., Zakaria, A., ve Zakaria, Z. (2011). Service Quality Dimensions in Public Library: Northern Area Experienced. Journal of Social Sciences, 7(2):265-270.

Zeithaml, V. A. ve Bitner, M.J. (2000). Services Marketing. Mcgraw Hill, Second Editon, New York.

Zengin, E. ve Erdal, A. (2005). Hizmet Sektöründe Toplam Kalite Yönetimi. Qafqaz Üniversitesi Dergisi, Ocak Sayısı:3-25. 